\title{
THE EFFECTS OF PROMOTION MIX ON CUSTOMERS' BUYING DECISION
}

\author{
Adrian Ekky A. Wahyudi \& Tina Melinda \\ Graduate School, Universitas Ciputra Surabaya, Surabaya, Indonesia
}

\begin{abstract}
The purpose of the research is to determine the effect of promotion mix, namely, advertising, personal selling, and public relations on buying decision. The population of the research included the consumers of Warung Ndeso Jancuocok. While the numbers of samples using Slovin showed 85.7, the researcher decided to take 89 respondents for this research. Sixteen questions in the questionnaire were used to collect data, weighted by Likert scale. The research was conducted from October to November 2017. This present study used multiple regression analysis and validity - reliability tests. Hypothesis testing was performed using F test, $t$ test, correlation coefficient of determination and partial determination coefficient. The research used classical assumption test such as multicollinearity test, heteroskedastic test, autocorrelation test, normality test and linearity test. This study found that Advertising and Personal Selling had a significant effect on customers' buying decisions. Meanwhile, public relation variable had no significant effect on customers' buying decisions.
\end{abstract}

Keywords: advertising, personal selling, public relations, buying decision

\section{Introduction}

The number of the people in Surabaya has increased from 2008 to 2013, except in 2010. The following is the description of Surabaya's population according to Badan Pusat Statistik Surabaya: 2.902.507 in 2008, 2.938.225 in 2009, 2.929 .528 in $2010,3.024 .321,3.125 .576$ in 2012, and 3.200.454 in 2013. These data show that Surabaya has a good development in terms of the number of population. In 2014, the number of the people was dramatically decreasing into 2.853.661. In 2015, the population reached 2.943.528.

While the population in Surabaya has increased, the needs of the people are also expanded. The skill to take advantage of opportunities and execute the plans becomes the neces-

*Corresponding Author. e-mail: adrian.ekky@hotmail.com sities. People who could do this sometimes are called entrepreneurs. According to Barringer and Ireland (2008), the word entrepreneurs was derived from French's entre which means "a between". However, prende means "take”. Thus, entrepreneur means a man who is dare to take risk between a buyer and seller or people who run a business. In other words, entrepreneur is a man who is able to see and execute an opportunity between a buyer and a seller. For that reason, the word Investor and Entrepreneur have a wider meaning. Investor means to create something; however, entrepreneur is a man who is able to integrate all the capitals, human resource, business model, strategy, and a risk to create a sustainable business (Barringer \& Ireland, 2008).

Kahyangan Group Restaurant, one of the biggest restaurants in Surabaya, also tries to see an opportunity and create something new. Kahyangan Group has already had Kahyangan 
Adrian Ekky A. Wahyudi \& Tina Melinda / The Effects of Promotion Mix on Customers' Buying Decision / JEE, Vol. 7, No. 2, September 2018, pp 63-70

Art and Resto in G-Walk Surabaya, Dewandaru Resto in Mayjen Sungkono Surabbaya, Mango Terrace Resto in Margorejo and the new one was Warung Ndeso Jancuocok in Siwalankerto Timur Surabaya. The new one is far different from the others, it is a middle low restaurant which is intended to compete with other middle low class restaurants. The rest is a premium class restaurant. Handling a new class resto especially in middle low - such as Warung Ndeso Jancuocok/JC is not easy to start such as

Out of all Kahyangan Group Restos, few obstacles have been identified when running the business to lower middle class since last year. The resulting turnover was not satisfactory and more likely to lead to minus. This was due to the shortage of improper promotional strategy by Warung Ndeso Jancuocok.

\section{GROSS PROFIT Of KAHYANGAN GROUP RESTO 1st SEMESTER 2017}
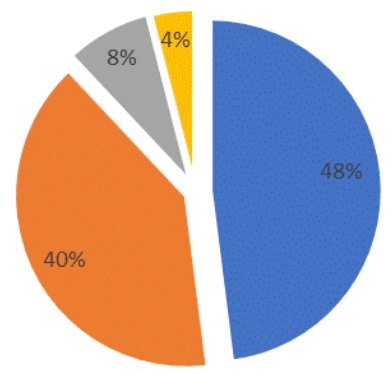

- KAHYANGAN ART RESTO - DEWANDARU RESTO - MANGOTERRACE " WARUNG NDESO JANCUOCOK

Figure 1 Contributions Omzet Kahyangan Group Semester I Year 201

From all branches of Kahyangan Group Resto, JC only contributed $4 \%$ in the first half of 2017. Mango Terrace contributing $8 \%$ in February 2017 was closed for renovation. Dewandaru Resto and Kahyangan Art Resto gave 40\% and 48\% for Kahyangan Group Resto.

Regarding promotion strategies undertaken by each branch of Kahyangan Group Resto, JC has had more activities than other branches.
Kotler (2012) explains that the mix promotion or promotion mix is divided into five sections, namely, advertising, sales promotion, personal selling, public relations, and direct marketing. In the first promotional mix, advertising is a way in which product/service introductions are made on a paid basis (Kotler \& Keller, 2012). In the execution plan of advertising, the objectives should be more clarified so that the desired action and results can be appropriate. The second is sales promotion which is useful to increase short-term sales through several ways such as sampling, coupon, free trial, sale of special price of display goods, etc. (Kotler \& Keller, 2012). The third is personal selling. This is one way of promotion that has been done for a long time and aims to sell products personally. Many names have been used in personal selling such as salesmen/salespeople, sales representatives, agents, account executives, and sales consultants. (Kotler \& Armstrong, 2012). Fourth is a public relation. The purpose of public relations is to build good relations with outsiders by maintaining a good image owned by the company while being capable of arranging in such a way that unfavorable news can be muted, (Kotler \& Armstrong, 2012). Honey is a consumer-focused marketing that has been predetermined, so sales can be focused and accurate. This can be done through an internet, television, telephone and others (Kotler \& Armstrong, 2012).

The typical of the promotion was almost similar with the others in Kahyangan Group Resto - which social media oriented. In fact, the target of the customers was the people or the students who are living around Warung Ndeso JC. As a result, the gross profit was never able to cover the operational of the restaurant. Based on the fact that made Warung 


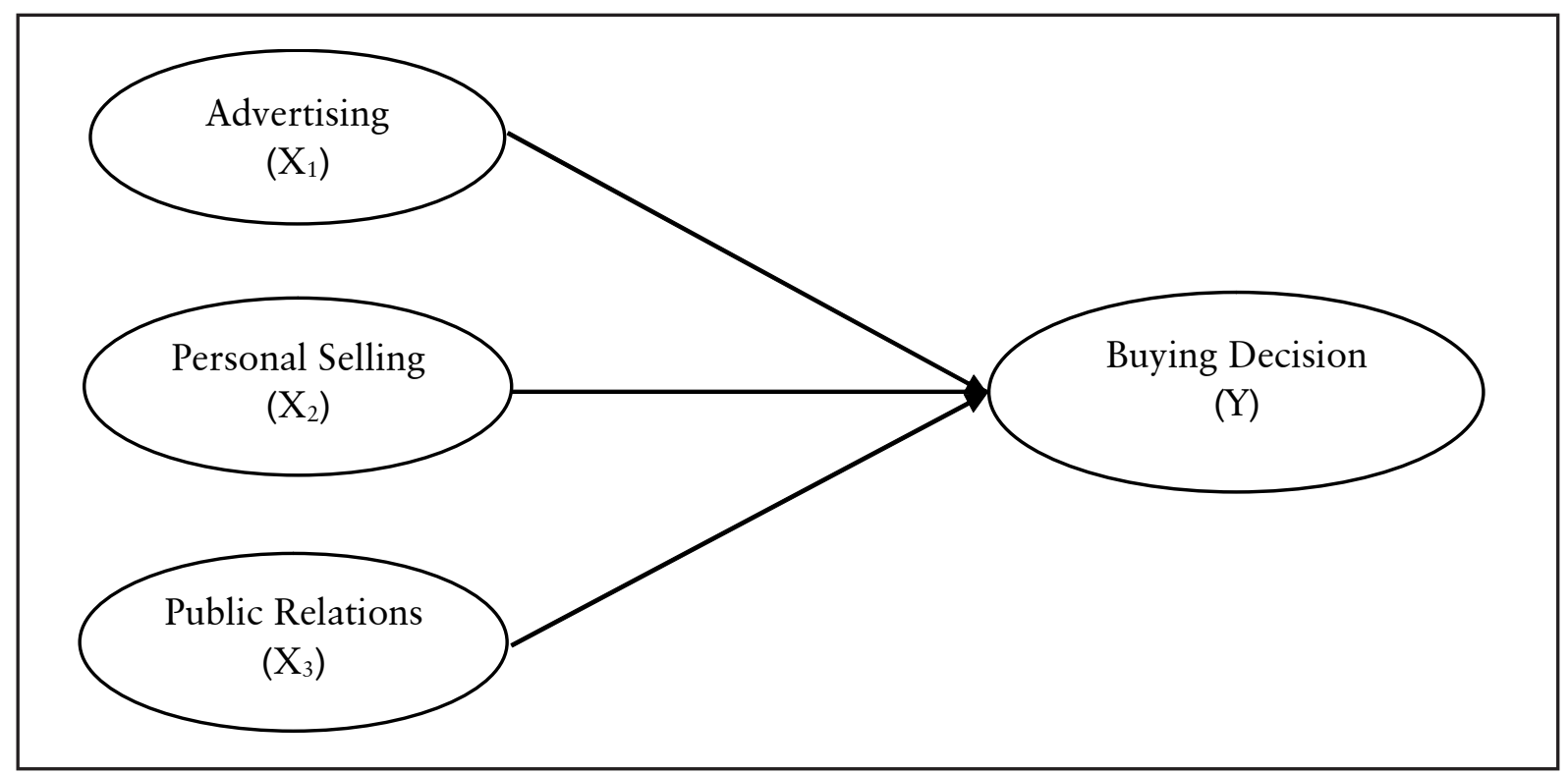

Figure 2 Conceptual Model

Ndeso JC was decreasing in the gross profit, the researcher wanted to determine what the best promotion for Warung Ndeso JC itself through promotion mix.

In this study, there were several independent variables X1 (advertising), X2 (personal selling), X3 (direct marketing). The dependent variable $\mathrm{Y}$ included customers' purchasing decisions. The conceptual model is described in Figure 2 .

Based on previous research and the above theories, the hypothesis of this research are formulated as follows:

$\mathrm{H} 1$ : Advertising has significant effect on purchasing decision.

$\mathrm{H} 2$ : Personal Selling has significant effect on purchasing decision.

H3: Public Relations significantly influence purchasing decisions.

\section{Method}

It is a quantitative research. $\mathrm{X}$ variable set is a promotional mix consisting of advertis- ing, personal selling and public relations. Meanwhile, Y variable is the consumers' buying decision. This research was held at Warung Ndeso Jancuocok Surabaya, Jl. Siwalankerto Timur No. 241, Siwalankerto, Wonocolo, Surabaya. The research took place in October 2017. This research entitled " The Effects Of Promotion Mix On Customers' Buying Decision.” The population included the customers of X Restaurant. The samples were selected through nonprobability sampling technique. This technique determines the samples by chance (Sugiyono, 2014). The criteria for the selection of the samples were as follows: they were the consumers or using products/services from Warung Ndeso Jancuocok. To determine the sample size, this preset study used Slovin method (Windasari, 2017) with a 10\% error rate. The population was assumed to cover 10 tables per day. If 1 table consisted of 2 people all customers would include 20 people. In a month there would be as many as 600 people. Using the Slovin formula, 85.7 was rounded to 89 . The data collection technique used a questionnaire 
Adrian Ekky A. Wahyudi \& Tina Melinda / The Effects of Promotion Mix on Customers' Buying Decision / JEE, Vol. 7, No. 2, September 2018, pp 63-70

that is to provide a set of written questions to respondents to be answered with a Likert scale measurement from Strongly Disagree (1), Disagree (2), Neither Agree or Disagree (3), Agree (4), and Strongly Agree (5).

\section{Results}

If the sig value is $<0.05$, then the question items are considered to be fulfilled. Based on the results of reliability tests on this questionnaire, Cronbach Alpha values was greater than

Table 1 The Results of Item Analysis and Reliability Test

\begin{tabular}{|c|c|c|c|c|}
\hline Test & Variable & Variable & $\begin{array}{c}\text { Pearson } \\
\text { Correlation }\end{array}$ & Sig (2-tailed) \\
\hline Item & Advertising & $\mathrm{X} 1.1$ & 0.592 & 0.000 \\
\hline \multirow[t]{15}{*}{ Analysis } & & X1.2 & 0.761 & 0.000 \\
\hline & & $\mathrm{X} 1.3$ & 0.693 & 0.000 \\
\hline & & $\mathrm{X} 1.4$ & 0.676 & 0.000 \\
\hline & Personal Selling & $\mathrm{X} 2.1$ & 0.651 & 0.000 \\
\hline & & $\mathrm{X} 2.2$ & 0.798 & 0.000 \\
\hline & & $\mathrm{X} 2.3$ & 0.737 & 0.000 \\
\hline & & $\mathrm{X} 2.4$ & 0.839 & 0.000 \\
\hline & Public & X3.1 & 0.915 & 0.000 \\
\hline & Relations & X3.2 & 0.913 & 0.000 \\
\hline & Buying & Y.1 & 0.647 & 0.000 \\
\hline & Decision & Y.2 & 0.578 & 0.000 \\
\hline & & Y.3 & 0.583 & 0.000 \\
\hline & & Y.4 & 0.584 & 0.000 \\
\hline & & Y.5 & 0.516 & 0.000 \\
\hline & & Y.6 & 0.593 & 0.000 \\
\hline Test & Variable & Indicator & $\begin{array}{c}\text { Cronbach's } \\
\text { Alpha if Item } \\
\text { Deleted }\end{array}$ & $\begin{array}{c}\text { Cronbach's } \\
\text { Alpha }\end{array}$ \\
\hline Reliability & Advertising & $\mathrm{X} 1.1$ & 0.577 & 0.612 \\
\hline \multirow[t]{15}{*}{ Test } & & $\mathrm{X} 1.2$ & 0.527 & \\
\hline & & $\mathrm{X} 1.3$ & 0.543 & \\
\hline & & X1.4 & 0.515 & \\
\hline & Personal Selling & $\mathrm{X} 2.1$ & 0.748 & 0.753 \\
\hline & & $\mathrm{X} 2.2$ & 0.657 & \\
\hline & & $\mathrm{X} 2.3$ & 0.706 & \\
\hline & & $\mathrm{X} 2.4$ & 0.653 & \\
\hline & Public & X3.1 & . & 0.803 \\
\hline & Relations & X3.2 & . & \\
\hline & Buying & Y.1 & 0.531 & 0.603 \\
\hline & Decision & Y.2 & 0.546 & \\
\hline & & Y.3 & 0.581 & \\
\hline & & Y.4 & 0.552 & \\
\hline & & Y.5 & 0.604 & \\
\hline & & Y.6 & 0.538 & \\
\hline
\end{tabular}


0.6. This indicates that the questions are reliable.

Multiple regression analysis is used if the researcher wants to see how the rise and fall of independent variables, if two or more independent variables as predictor factor is manipulated (ascended lower in value).

Table 2 The Result of Multiple Linear Regression

\begin{tabular}{lrrrr}
\hline \multicolumn{1}{c}{ Model } & Coefficient & $\begin{array}{c}\text { Beta } \\
\text { Values }\end{array}$ & $\mathrm{T}$ & Sig. $\mathbf{~}$ \\
\hline Constanta & 2.174 & & 5.379 & 0.000 \\
Advertising & 0.331 & 0.353 & 3.648 & 0.000 \\
Personal & 0.223 & 0.332 & 3.529 & 0.001 \\
Selling & & & & \\
Public & -0.86 & -0.187 & -1.958 & 0.54 \\
Relation & & & & \\
R & & & 0.520 & \\
$\mathrm{R}^{2}$ & & & 0.270 & \\
F & & & 10.494 & \\
Sig F & & & 0.000 & \\
\hline
\end{tabular}

The coefficient value resulting from Advertising variable is 0.331 and significant. The positive sign resulting from the regression coefficient means that there is a direct relationship between the variables Advertising and Purchase Decision. Coefficient value resulting from variable of Personal Selling is equal to 0,223 and thus it is significant. The positive sign resulting from the regression coefficient means that there is a direct relationship between Personal Selling and Purchase Decision variables. The value of coefficient generated from the variable Public Relations is equal to -0.86 and not significant. The negative sign resulting from the value of the regression coefficient means that there is an inverse relationship between Public Relations and Purchase Decision variables. This is in accordance with the circumstances in the field where Warung Ndeso JC only performs free morning gymnastics events every Sunday. In addition, it also provides a place for RT/RW meetings every month. The consumers do not feel satisfied with the activities of Public Relations in Warung Ndeso JC. Based on the calculation of the correlation coefficient $(\mathrm{R})$ with the value of 0.520 , the relationship between Advertising, Personal Selling, and Public Relations variables with Purchase Decision in Warung Ndeso JC are strong. For the calculation of the coefficient of determination symbolized by (R2) with the value of 0.270 it can be explained that the variables Advertising, Personal Selling, and Public Relations simultaneously affect the Purchase Decision at Warung Ndeso Jancuocok with a value of $27.0 \%$. While the rest of $73.0 \%$ is influenced by other variables-other than Advertising, Personal Selling, and Public Relations.

Table 3 Multicollinearity, Heteroscedasticity, Autocorrelation, Normality, Linearity Test Results

\begin{tabular}{llcc}
\hline & Variable & \multicolumn{2}{c}{ Collinearity Statistics } \\
& Tolerance & VIF \\
\hline \multirow{3}{*}{ Multicollinearity } & Advertising & 0.914 & 1.094 \\
& Personal Selling & 0.970 & 1.031 \\
& Public Relations & 0.939 & 1.065 \\
\hline & Variable & Significancy \\
& Advertising & 0.461 \\
& Personal Selling & 0.922 & \\
Heteroscedasticity & Public Relations & 0.818 & \\
& "dependent variable: abs_res & DW & 4-du \\
\hline \multirow{2}{*}{ Autocorrelation } & du & 1,805 & 2,2736 \\
\hline \multirow{2}{*}{ Normality } & Criteria & Results \\
& Kolomogorov Smirnov Z & 0.81 & \\
\hline & Significance & 0.200 & \\
\hline \multirow{2}{*}{ Linearity } & Linearity Relationships & F & Significance \\
& Purchase Decision * Advertising & 0.313 & 0.904 \\
& Purchase Decision * Personal Selling & 1.188 & 0.317 \\
& Purchase Decision * Public Relations & 1.797 & 0.123 \\
\hline
\end{tabular}

The above results explain that the VIF value is less than 10 whereas, the tolerance value alone is less than 0.1. So it can be concluded that there is no multicollinearity in this free regression model.

The multicollinearity test is used to find whether there is a perfect linear relationship in the independent variable in the regression model used. If the tolerance value $>0.1$ and the VIF value $<10$, then the regression model used is 
Adrian Ekky A. Wahyudi \& Tina Melinda / The Effects of Promotion Mix on Customers' Buying Decision / JEE, Vol. 7, No. 2, September 2018, pp 63-70

free from multicollinearity. Heteroscedasticity test is used to indicate whether there is an inequality or no variance inequality of the residual upon observation to another observation. If the value of correlation significance above the value of $0.05(\alpha=5 \%)$, meaning no heteroscedasticity occurs in this regression model. Heteroscedasticity test using Glejser test.

From the above results can be explained that the value of correlation sig of the Advertising variable of 0.461 , Personal Selling variable is 0.922; meanwhile Public Relations variable is 0.818 . Both of these variables have significance value above 0.05 . Thus, it can be concluded that the regression model in this study does not occur in heteroscedasticities covering Advertising, Personal Selling and Public Relation variables. This test is used to see if there is a correlation between residual (look for other sources). To find out whether there is any correlation using the Durbin-Watson test, DW value should be less than 4-du, and should be more than du. $\mathrm{K}=3$, $\mathrm{dU}=1.7264$

The result of the Durbin-Watson regression is 1.805 where this value is between the $\mathrm{du}$ values of 1.7264 and the 4 -du value of 2.2736. So it can be concluded if there is no autocorrelation in this regression model. The purpose of the normality test is to see the residual of this regression model following the normal distribution. Testing can be done by using Kolmogorov Smirnov test. If the value of sig $>0.05(\alpha$ $=5 \%)$, it means the distribution on the residual regression model is normal. Based on the results of the normality test above, the sig value is greater than 0.05 with the acquisition value of 0.200. Then, it can be concluded that this regression model is normally distributed. Linearity test is used to find whether the variables used in this study have a linear relationship.
The test to be used is Deviation from Linearity. If the resulting value is above 0.05 , then the tested variable can be said to have a linear relationship.

Based on the above results, indicates that the Advertising variable has an $\mathrm{F}$ value of Deviation from Linearity of 0.313 with sig 0.904 . Personal Selling has $\mathrm{F}$ value of Deviation from Linearity equal to 1,188 with sig 0.317 While for Public Relation has value of $\mathrm{F}$ from Deviation from Linearity equal to 1,797 with value of sig 0.123. This shows that Advertising and Personal Selling have a linear relationship with Purchase Decision.

\section{Discussion}

Advertising gives partially significant effect on Purchase Decision at Warung Ndeso Jancuocok. The advertising in Warung Ndeso JC has only focused on the Persuasive Objective. More issues need to be expanded in accordance with the objectivity of these ads, Budget Determination, and Messages. In the future, it is expected that the advertising run by Warung become increasingly varied with certain goals as said Kotler \& Armstrong (2012), in addition to more attractive design.

Personal Selling give partial effect on Purchase Decision. For this type of restaurant business, salespeople are very influential in helping to learn about market products / services from the restaurant. According to Kolter and Armstrong (2012), personal selling has several personal selling stages from prospecting-qualifying, preapproach, approach, presentation and demonstration, handling objections, closing and follow up. With these guidelines, the salesperson's expectation from Warung Ndeso JC is also getting better not only in presentation and 
demonstration, but also in approaching prospective consumers to follow-up at the beginning. This study found that the lowest average is generated by X2.4: "Warrior Warrior Ndeso $\mathrm{JC}$ is able to inform JC products", then focus on giving the Salesman training in handling objections into something that must be immediately fixed.

It can be said that Public Relations partially does not affect Purchase Decision at Warung Ndeso JC. If linked to what has been explained to Kotler \& Armstrong (2012) on Public Relations, Warung Ndeso JC only puts itself in the development section. It focuses on non-profit activities and communities. Meanwhile, Public Relations consists of press relations, product publicity, public affairs, lobbying, investor relations. Therefore, in the future Warung Ndeso JC has to focus on other objectivities. They should not only stay in place at the development stage.

\section{References}

Barringer B.R. dan Ireland R.D. 2008. Entrepreneurship: Successfully Launching New Ventures, 4th ed. s.l.: Prentice Hall.

Kotler, P. \& Amstrong, G. 2012. Principles of Marketing. 14th ed. New Jersey: Pearson Prentice Hall.

Kotler, P. \& Keller, K.L. 2012. Marketing Management. 14th ed. New Jersey: Prentice Hall.

Statistik, B.P. 2017. Badan Pusat Statistik Surabaya. [Online]. https://surabayakota.bps. go.id/index.php/publikasi/index?Publikasi \%5BtahunJudul\%5D=\&Publikasi\%5Bkata Kunci\%5D $=$ surabaya + dalam + angka\&yt $0=$ Tampilkan [Accessed 3 Juli 2017].

Sugiyono. 2014. Metode Penelitian Bisnis. 18th ed. Jakarta: Alfabeta.

Windasari, K.A. 2017. Analisis Segmentasi Pasar Cui House Laundry dengan Pendekatan Cluster Analysis. Surabaya: Universitas Ciputra. 
Adrian Ekky A. Wahyudi \& Tina Melinda / The Effects of Promotion Mix on Customers' Buying Decision / JEE, Vol. 7, No. 2, September 2018, pp 63-70 